\title{
THE APPLICATION OF LEARNING WITH COGNITIVE CONFLICT APPROACH IN IMPROVING UNDERSTANDING CONCEPT OF PHYSICS OF CLASS VIII STUDENTS OF SMP 40 PEKANBARU
}

\author{
Emiliani $^{* 1)}$, Zulirfan $^{2)}$, Fakhruddin $^{3)}$, Februartati ${ }^{4)}$ \\ ${ }^{1,2,3)}$ Physics Education, Riau University \\ 4) Teacher, SMP 40 Pekanbaru \\ e-mail: emiliani354@gmail.com \\ zirfanaziz69@gmail.com \\ faruqfisika@yahoo.com \\ februartati@gmail.com
}

\begin{abstract}
This study aims to determine the improvement of conceptual understanding of physics of class VIII students of SMP Negeri 40 Pekanbaru on the topic of light and optical through learning with cognitive conflict approaches. The type of this research is quasi experiment with population of 172 students of class VIII SMP Negeri 40 Pekanbaru consisted of 4 classes. Two classes were selected to be a research sample based on normality and homogeneity tests on repetition of sound material to obtain experimental and control classes, each of 43 people. The data collected by giving the physics' conceptual understanding test in Bloom's taxonomy in the form of two tier multiple choice with 14 items. This instrument consists of 7 indicators of conceptual understanding, namely: interpretation, modeling, classifying, summarizing, drawing inference, comparing, and explaining. The result of the research showed that the ability of studens' concept understanding after the application of learning with cognitive conflict approach was in the good category. The average score of the students' understanding of the physics concept on the experimental group was higer than the average score of the control group. it can be concluded that learning with cognitive conflict approach can improve conceptual understanding of physics of class VIII SMP Negeri 40 Pekanbaru student on the topic of light and optics.
\end{abstract}

Keywords: conceptual understanding of physics, cognitive conflict approach, light and optics.

\section{PENERAPAN PEMBELAJARAN DENGAN PENDEKATAN KONFLIK KOGNITIF DALAM MENINGKATKAN PEMAHAMAN KONSEP FISIKA SISWA KELAS VIII SMP NEGERI 40 PEKANBARU}

\author{
Emiliani $^{* 1)}$, Zulirfan $^{2)}$, Fakhruddin $^{3)}$, Februartati ${ }^{4)}$ \\ ${ }^{1,2,3)}$ Pendidikan Fisika, Universitas Riau \\ 4) Guru, SMP N 40 Pekanbaru
}

\begin{abstract}
Abstrak
Penelitian ini bertujuan untuk mengetahui peningkatan pemahaman konsep fisika siswa kelas VIII SMP Negeri 40 Pekanbaru pada topik materi cahaya dan optik setelah penerapan pembelajaran dengan pendekatan konflik kognitif. Jenis penelitian ini adalah kuasi eksperimen dengan populasi 172 siswa kelas VIII SMP Negeri 40 Pekanbaru yang terdiri dari 4 kelas. Dua kelas terpilih menjadi sampel penelitian berdasarkan tes
\end{abstract}


normalitas dan homogenitas pada ulangan materi bunyi sehingga diperoleh kelas eksperimen dan kelas kontrol, masing-masing 43 orang. Pengumpulan data dilakukan dengan memberikan tes pemahaman konsep dalam taksonomi Bloom yang berbentuk two tier multiple choice dengan 14 butir soal yang terdiri dari 7 indikator pemahaman konsep yaitu: interpretasi, mencontohkan, mengklasifikasi, meringkas, menarik inferensi, membandingkan, dan menjelaskan. Hasil penelitian menunjukkan kemampuan pemahaman konsep siswa setelah penerapan pembelajaran dengan pendekatan konflik kognitif dalam kategori baik, sedangkan skor rata-rata pemahaman konsep fisika siswa kelompok eksperimen lebih tinggi dari skor rata-rata kelompok kontrol. Maka dapat disimpulkan bahwa pembelajaran dengan pendekatan konflik kognitif dapat meningkatkan pemahaman konsep fisika siswa kelas VIII SMP Negeri 40 pada topik materi cahaya dan optik.

Kata Kunci: pemahaman konsep fisika, pendekatan konflik kognitif, cahaya dan optik.

\section{Pendahuluan}

IPA merupakan cara mencari tahu tentang alam secara sistematis. Untuk itu, proses pembelajaran IPA haruslah menekan kan pada penyediaan pengalaman langsung bagi para siswa agar potensi yang mereka miliki berkembang dalam memahami dan tersu mempelajari alam sekitar. Oleh karena itu, IPA bukanlah suatu kumpulan pengetahuan saja namun juga merupakan suatu proses penemuan.

Fisika adalah salah satu cabang IPA yang mempelajari gejala-gejala alam melalui proses ilmiah. Sama halnya dengan cabang IPA lainnya, ilmu fisika dibangun atas dasar sikap ilmiah dan hasilnya terwujud sebagai suatu produk ilmiah yang bermanfaat dalam perkembangan ilmu pengetahuan dan teknologi. Pembelajaran fisika menekankan adanya inkuiri ilmiah dengan tujuan untuk menumbuhkan kemampuan berfikir siswa (Depdiknas, 2006).

Kemampuan berfikir siswa di tingkat pendidikan dasar dan menengah saat ini umumnya masih sangat rendah. Hal ini dikarenakan pembelajaran yang dilaksanakan cenderung masih bersifat hafalan teori dan tidak didasarkan pada pengalaman siswa sehingga siswa cenderung menghafal materi yang diajarkan oleh guru (Umrotun, 2012). Oleh karena itu, tidaklah mengherankan bahwa pada umumnya pembelajaran fisika masih dirasakan sebagai pelajaran yang sulit bagi siswa. Sebahagian besar siswa kurang memahami formulasi-formulasi dari suatu konsep fisika yang dipelajari sehingga timbul rasa ketidakyakinan, kebingungan dan keraguan terhadap materi yang disampaikan guru (Setyowati et al., 2011).

Seorang siswa dikatakan memahami suatu konsep apabila memiliki kemampuan untuk mengerti dan memahami suatu konsep tersebut dari berbagai segi dan dapat menjelaskan lebih rinci mengenai konsep tersebut menggunakan kata-kata mereka sendiri (Ela Suyani et al., 2016). Tingkat pemahaman siswa terhadap suatu konsep dapat dilihat dari jenis-jenis pemahaman yang dimilikinya. Bloom (dalam Ari widodo, 2005) membagi kategori pemahaman konsep menjadi beberapa indikator yaitu interpretasi, mencontohkan, mengklasifikasi, meringkas, menarik inferensi, membandingkan, dan menjelaskan.

Materi cahaya dan optik merupakan bagian dari pelajaran fisika yang cukup penting untuk diajarkan di tingkat SMP. Materi cahaya dan optik mengandung konsepkonsep fisika yang banyak diterapkan dalam kehidupan sehari-hari. Oleh karena itu, materi cahaya cukup sulit dipahami oleh siswa di sekolah. Salah satu contoh pemahaman konsep yang bermasalah adalah sebagian besar siswa menganggap bahwa konsep hukum refleksi yakni kesamaan sudut datang dengan sudut pantulhanya terjadi pada cermin datar. Padahal juga terjadi pada cermin cekung dan cermin cembung (Paul Suparno, 2007).

Proses pembelajaran fisika yang benar haruslah mengembangkan perubahan konsep. Perubahan konsep yang dimaksud adalah perubahan perluasan suatu konsep dari yang belum lengkap menjadi lengkap dan pembenaran suatu konsep yang salah menjadi benar. Menurut Posner, dalam proses pembelajaran ada dua proses yang berkaitan 
dengan perubahan konsep yaitu asimilasi dan akomodasi (Paul Suparno, 2007). Asimilasi adalah proses pengumpulan dan pengelompok kan informasi baru, yang mana siswa akan menggunakan konsep yang telah ada untuk berhadapan dengan fenomena baru. Sedangkan akomodasi merupakan pembentukan struktur baru yang sesuai dengan rangsangan yang baru atau memodifikasi konsep yang sebelumnya telah tersimpan dalam struktur kognitif sehingga cocok dengan rangsangan baru yang dihadapi. Peran guru dalam proses pembelajaran adalah sebagai fasilitator yang membawa siswa berfikir lebih tinggi dengan catatan siswa sendiri yang harus menemukan dan menerapkan ide-ide tersebut (Trianto, 2007).

Mengatasi masalah tersebut, maka guru perlu memperbaiki proses pembelajaran di dalam kelas. Perbaikan tersebut dapat dilakukan dengan menerapkan suatu pembelajaran yang membantu siswa memperbaiki konsepnya, salah satunya yaitu dengan menerapkan pendekatan konflik kognitif. Mosik \& Maulana (2010) menyatakan pendekatan konflik kognitif merupakan salah satu pendekatan pembelajaran yang dikembangkan dari pandangan Piaget. Pendekatan konflik kognitif melibatkan siswa secara aktif dalam proses pembelajaran dengan tujuan untuk membantu siswa melakukan pengelompokkan ulang pengetahuan yang sebelumnya telah tersimpan dalam struktur kognitifnya dengan melibatkan proses asimilasi dan akomodasi. Sementara itu, Fajar Subajikto (2015) menyatakan pembelajaran dengan pendekatan konflik kognitif dimulai dari tahap asimilasi, akomodasi dan equilibrasi.

Penelitian pendekatan konflik kognitif pada pembelajaran fisika telah dilakukan oleh Setyowati et al. (2011) yang membuktikan bahwa implementasi pendekatan konflik kognitif pada materi tekanan efektif digunakan untuk menumbuhkan kemampuan berfikir kritis, pemahaman konsep dan hasil belajar kognitif siswa kelas VIII SMP Muhammadiyah 3 Kaliwungu. Hal tersebut juga dibuktikan oleh Fajar Subajikto (2015) yang membuktikan bahwa strategi pembelajaran kontruktivisme dengan pendekatan konflik kognitif efektif dalam mengatasi miskonsepsi siswa dan dapat meningkatkan hasil belajar fisika siswa kelas XI SMP Negeri
16 Jakarta. Penelitian yang sama juga dilakukan oleh Mosik \& Maulana (2010) yang menyimpulkan bahwa pembelajaran dengan pendekatan konflik kognitif berpengaruh signifikan terhadap berkurangnya miskonsepsi siswa kelas VII SMP Negeri 1 Semarang.

Dalam penelitian ini peneliti menerap kan pembelajaran dengan pendekatan konflik kognitif untuk meningkatkan kemampuan pemahaman konsep fisika pada topik cahaya dan optik bagi sisiwa kelas VIII SMP Negeri 40 Pekanbaru. Dengan demikian tujuan penelitian ini adalah untuk mendeskripsikan pemahaman konsep fisika siswa kelas VIII SMP Negeri 40 Pekanbaru setelah penerapan pendekatan konflik kognitif dan mengetahui signifikan perbedaan pemahaman konsep fisika siswa kelas VIII SMP Negeri antara kelas yang menerapkan pembelajaran dengan pendekatan konflik kognitif dengan kelas yang menerapkan pembelajaran konvensional.

\section{Bahan dan Metode}

Jenis penelitian yang digunakan dalam penelitian ini adalah kuasi eksperimen dengan rancangan berbentuk intact group comparison. Populasi penelitian meliputi seluruh siswa kelas VIII SMP Negeri 40 Pekanbaru yang terdiri dari 4 kelas dan berjumlah 172 orang. Dua kelas yang terpilih menjadi sampel penelitian terdiri dari kelas eksperimen yaitu kelas VIII D yang berjumlah 43 orang dan kelas kontrol yaitu kelas VIII B yang berjumlah 43 siswa. Pemilihan kedua kelas dilakukan secara undian yang telah diuji homogenitas berdasarkan ulangan harian pada topik materi bunyi.

Pengumpulan data dilakukan dengan memberikan tes pemahaman konsep yang berbentuk two tier multiple choice sebanyak 14 butir soal pada kelas eksperimen yang menerapkan pendekatan konflik kognitif dan kelas kontrol yang menerapkan pembelajaran konvensional. Analisis data dilakukan secara deskriptif dan inferensial.

Analisis deskriptif dilakukan untuk memperoleh rata-rata skor akhir pemahaman konsep siswa pada materi cahaya dan optik untuk kelas eksperimen dan kelas kontrol. Penskoran tiap butir soal tes pemahaman konsep merujuk pada Tabel 1. 
Tabel 1. Pedoman penskoran instrumen two tier multiple choice

\begin{tabular}{lc}
\hline \multicolumn{1}{c}{ Kriteria } & Skor \\
\hline Tidak ada jawaban & 0 \\
Menjawab lebih dari satu & 0 \\
$\begin{array}{l}\text { Satu jawaban benar pada second } \\
\text { tier }\end{array}$ & 0 \\
Satu jawaban benar pada first tier & 1 \\
$\begin{array}{l}\text { Dua jawaban benar pada first and } \\
\text { second tier }\end{array}$ & 2 \\
\hline
\end{tabular}

Sumber: Ari Syahidul Shidiq et al. (2014).

Kategori pemahaman konsep siswa per indikator dapat ditentukan dengan persamaan:

$$
\% \mathrm{SPKS}=\frac{S T S}{S M} \times 100 \%
$$

Keterangan:

SPKS = Skor pemahaman konsep siswa

STS = Skor total siswa

$\mathrm{SM}=$ Skor maksimum

Kategori pemahaman konsep siswa rata-rata per indikator dan seluruh indikator dapat ditentukan dengan persamaan:

$$
\% \text { SPKSR }=\frac{J S S S}{J S} x 100 \%
$$

Keterangan:

SPKSR $=$ Skor pemahaman konsep siswa ratarata

JSSS = Jumlah skor seluruh siswa

JS = Jumlah seluruh siswa

Skor yang diperoleh siswa pada kelas eksperimen dan kelas kontrol berdasarkan persamaan (1) dan (2), selanjutnya dikategori kan pada kategori pemahaman konsep yang merujuk pada Tabel 2.

Tabel 2. Kategori pemahaman konsep siswa

\begin{tabular}{cc}
\hline Interval (\%) & Kategori \\
\hline $80<\mathrm{x} \leq 100$ & Baik sekali \\
$66<\mathrm{x} \leq 80$ & Baik \\
$56<\mathrm{x} \leq 66$ & Cukup \\
$46<\mathrm{x} \leq 56$ & Kurang \\
$0<\mathrm{x} \leq 46$ & Gagal \\
\hline
\end{tabular}

Sumber: Anas Sudijono (2009)

Sementara itu, analisis inferensial dilakukan untuk mengetahui signifikansi perbedaan pemahaman konsep fisika siswa antara kelas yang menerapkan pembelajaran pendekatan konflik kognitif dengan kelas yang menerapkan pembelajaran konvensional. Hipotesis nol yang akan diuji dalam penelitian ini adalah tidak terdapat perbedaan yang signifikan pada pemahaman konsep fisika siswa antara kelompok eksperimen dengan kelompok kontrol. Pengujian hipotesis menggunakan independent sampe t-test. Untuk kemudahan perhitungan, analisis inferensial menggunakan bantuan software SPSS versi 16.

\section{Hasil dan Pembahasan}

Hasil analisis deskriptif, tingkat pemahaman konsep fisika siswa kelas VIII SMP Negeri 40 Pekanbaru pada kelompok eksperimen yang menerapkan pendekatan konflik kognitif dan kelompok kontrol yang menerapkan pembelajaran konvensional ditunjukkan oleh Tabel 3.

Tabel 3. Deskripsi tingkat pemahaman konsep fisika siswa pada topik cahaya dan optik

\begin{tabular}{cccccc}
\hline & & \multicolumn{3}{c}{ Skor Rata-Rata Pemahaman Konsep } \\
\cline { 3 - 6 } No & Indikator & $\%$ & Kategori & $\%$ & Kategori \\
\cline { 3 - 5 } & & 75,60 & Baik & 60,71 & Cukup \\
\cline { 3 - 5 } 1 & Interpretasi & 73,21 & Baik & 60,71 & Cukup \\
2 & Mencontohkan & 64,29 & Cukup & 68,45 & Baik \\
3 & Mengklasifikasi & 66,67 & Baik & 50,00 & Kurang \\
4 & Meringkas & 71,43 & Baik & 68,45 & Baik \\
5 & Menarik Inferensi & 64,88 & Cukup & 57,14 & Cukup \\
6 & Membandingkan & 73,81 & Baik & 55,95 & Kurang \\
\hline 7 & Menjelaskan & 69,98 & Baik & 60,20 & Cukup \\
\hline
\end{tabular}


Tabel 3 menunjukkan bahwa skor ratarata pemahaman konsep fisika siswa pada kelas eksperimen lebih tinggi dari kelas kontrol dengan selisih skor sebesar 9,78\%. Pemahaman konsep siswa pada kelas eksperimen secara umum dikategorikan baik dengan skor sebesar 69,98\%. Meskipun demikian terdapat dua indikator yang berkategori cukup yaitu mengklasifikasi dan membandingkan.

Pemahaman konsep fisika siswa pada kelas kontrol dikategorikan cukup dengan skor rata-rata sebesar $60,20 \%$. Meskipun demikian terdapat beberapa indikator yang berada pada kategori baik yaitu mengklasifikasi dan menarik inferensi serta dua indikator berada pada kategori kurang yaitu meringkas dan menjelaskan.

Tabel 3 juga memperlihatkan bahwa berdasarkan indikator, skor pemahaman konsep fisika yang diperoleh siswa pada kelompok eksperimen cenderung lebih tinggi dibandingkan dengan kelompok kontrol, kecuali pada indikator mengklasifikasi. Pada indikator mengklasifikasi, skor yang diperoleh siswa kelompok kontrol lebih tinggi dibandingkan dengan kelompok eksperimen. Skor yang diperoleh siswa pada kelas kontrol sebesar 68,45\% dengan kategori baik sedangkan kelas eksperimen sebesar 64,29\% dengan kategori cukup baik.

Berdasarkan hasil perhitungan menggunakan SPSS versi 16 dengan taraf kepercayaan 95\% untuk uji beda dengan independent sample t-test di peroleh nilai signifikansi 2 tailed $\mathrm{t}=0,037, \mathrm{p}<0,05$. Hal ini menunjukkan bahwa terdapat perbedaan yang signifikan pada tingkat pemahaman konsep fisika siswa antara antara kelompok eksperimen dengan kelompok kontrol. Oleh karena skor rata-rata pemahaman konsep fisika kelompok eksperimen lebih tinggi dibanding kan skor rata-rata kelompok kontrol, maka dapat dijelaskan bahwa pemberian perlakuan yang dalam hal ini adalah penerapan pembelajaran dengan pendekatan konflik kognitif dapat meningkatkan kemampuan pemahaman konsep fisika siswa kelas VIII SMP Negeri 40 Pekanbaru khususnya pada topik materi cahaya.

\section{Kemampuan menginterpretasi}

Interpretasi merupakan kemampuan siswa dalam mengubah suatu bentuk informasi kebentuk informasi lainnya. Soal tes kemampuan interpretasi terdiri dari dua butir soal. Pada indikator interpretasi, rata-rata skor kelas eksperimen sebesar $75,60 \%$ sedangkan kelas kontrol sebesar $60,71 \%$. Perbedaan perolehan rata-rata skor pada kelas eksperimen dan kelas kontrol untuk indikator ini disebabkan di awal pembelajaran pada kelas eksperimen, siswa diberikan suatu permasalahan berkaitan dengan sifat perambatan cahaya yang sebagian besar disajikan dalam bentuk animasi sedangkan pada kelas kontrol permasalahan diberikan dalam bentuk tanya jawab kepada siswa.

Adanya perbedaan dalam memberikan permasalahan ini menyebabkan pemahaman siswa di kelas eksperimen lebih baik dibandingkan kelas kontrol karena pemberian animasi pada kelas eksperimen dapat melatih kemampuan berfikir siswa yaitu kemampuan dalam mengubah informasi sifat-sifat perambatan cahaya yang diperoleh dari pengamatan pada animasi menjadi informasi kata-kata yang disampaikan secara lisan sehingga siswa akan menjadi lebih paham. Hal ini didukung oleh pendapat Richard \& Roxana Moreno (2002) yang menyatakan bahwa pemberian media animasi dapat menaikkan pemahaman siswa dan memberikan kemudahan siswa dalam memahami suatu konsep. Perolehan skor rata-rata kelas kontrol yang lebih rendah $15,79 \%$ dari kelas eksperimen dikarenakan siswa masih kesulitan dalam memahami konsep pada gambar yang disajikan pada soal tes.

\section{Kemampuan mencontohkan}

Mencontohkan berkaitan dengan kemampuan siswa dalam memberikan contoh dari suatu konsep tertentu. Soal tes kemampuan mencontohkan terdiri dari dua butir soal. Pada indikator mencontohkan ini, rata-rata skor siswa kelaseksperimen sebesar $73,21 \%$ dan kelas kontrol sebesar 60,71\%. Perbedaan perolehan skor rata-rata ini dikarenakan pada kelas eksperimen, pengenalan masalah yang disajikan berhubungan dengan contoh dari gejala sifat-sifat perambatan cahaya yang terjadi dalam kehidupan sehari-hari sehingga membantu siswa dalam mengaitkan antara apa yang dipelajari dengan keadaan yang terjadi dalam kehidupan sehari-hari. Hal ini didukung oleh pendapat Ela Suryani (2016) yang menyatakan 
bahwa bila pembelajaran selalu dikaitkan dengan permasalahan dalam kehidupan seharihari maka pemahaman konsep yang diperoleh siswa akan bertahan lama dan akan meminimalisir kesalahan pemahaman yang berasal dari pengalaman yang pernah dialami oleh siswa dalam kehidupan sehari-hari. Rendahnya skor yang diperoleh siswa pada kelas kontrol dikarenakan siswa kurang mampu memahami contoh dari gejala suatu konsep.

\section{Kemampuan mengklasifikasi}

Mengklasifikasi merupakan kemampuan dalam mengenali ciri-ciri atau sifat dasar suatu benda atau fenomena yang termasuk pada konsep tertentu. Soal tes kemampuan mengklasifikasi ini terdiri dari dua butir soal. Rata-rata skor yang diperoleh siswa pada kelas eksperimen untuk indikator mengklasifikasi ini lebih rendah $4,16 \%$ dibandingkan kelas kontrol. Rata-rata skor kelas eksperimen sebesar 64,29\% sedangkan kelas kontrol sebesar $68.45 \%$. Rendahnya skor yang diperoleh siswa pada kelas eksperimen dikarenakan siswa kesulitan membedakan sifat cahaya saat mengenai cermin dan lensa. Sebagian besar siswa menganggap ketika cahaya mengenai permukaan cermin dan lensa maka cahaya akan diteruskan. Hal ini didukung oleh pendapat Aydin (dalam Sri Lestari Handayani \& Diki Rukmana, 2018) yang menyatakan bahwa banyak siswa yang beranggapan ketika cahaya melewati cermin cekung dan cermin cembung maka cahaya akan dibiaskan masuk ke belakang cermin.

\section{Kemampuan meringkas}

Meringkas berkaitan dengan kemampuan siswa dalam merangkum sebuah informasi yang disajikan. Soal tes kemampuan meringkas ini terdiri dari dua butir soal. Ratarata skor siswa kelas eksperimen sebesar $66,67 \%$ dan rata-rata skor siswa kelas kontrol adalah 50,00\%. Perbedaan skor ini dikarena kan di kelas eksperimen, siswa diberikan LKS tentang sifat-sifat perambatan cahaya, pemantulan cahaya dan pembiasan cahaya, berisi pertanyaan yang berkaitan dengan kegiatan percobaan yang dilakukan sesuai dengan materi pada LKS. Pertanyaanpertanyaan ini sebagian besar melatih siswa untuk merangkum informasi yang diperoleh dari hasil percobaan dan siswa diminta untuk berdiskusi dalam menyelesaikan pertanyaan tersebut.

Adanya diskusi kelompok ini maka dapat melatih kemampuan berfikir siswa untuk mengemukakan idenya dalam membuat suatu rangkuman dari hasil percobaan sifat perambatan cahaya, pemantulan cahaya, pembiasan cahaya dan siswa akan lebih mengingat apa yang didiskusikan daripada menerima penjelasan dari guru. Hal ini didukung oleh pendapat Syifa Ulya et al., (2013) yang menyatakan berdiskusi merupa kan cara belajar yang menuntut siswa mengembangkan pengetahuan melalui kombinasi dua pemikiran karena setiap siswa memiliki pandangan yang berbeda-beda sehingga siswa akan berusaha belajar bersama agar ilmu yang didapat lebih bermakna.

\section{Kemampuan menarik inferensi}

Menarik inferensi merupakan kemampuan siswa dalam membuat kesimpulan yang logis dari informasi yang disajikan. Soal tes kemampuan menarik inferensi ini terdiri dari dua butir soal. Rata-rata skor siswa kelas eksperimen sebesar $71,43 \%$ sedangkan ratarata skor siswa kelas kontrol sebesar $68,45 \%$.

Perbedaan rata-rata skor ini dikarenakan pada kelas eksperimen, siswa diberikan LKS tentang sifat perambatan cahaya, pemantulan cahaya dan pembiasan cahaya yang berisi prosedur kegiatan yang membantu siswa dalam melakukan percobaan, mengolah data hasil percobaan dan membuat suatu kesimpulan yang benar tentang suatu konsep sesuai dengan materi yang disajikan pada LKS. Sehingga siswa dapat menyesuaikan kembali antara pengetahuan awalnya dengan informasi yang diperoleh dari hasil percobaan. Hal ini didukung oleh pendapat Miftahul Huda (2011) yang menyatakan bahwa pembelajaran dengan pendekatan konflik kognitif merupa kan katalisator perubahan karena dapat memotivasi siswa untuk merenungkan kembali pemahamannya terhadap suatu masalah dan berusaha untuk mengkonstruk pemahaman baru yang lebih sesuai dengan feedback yang diterima. Sedangkan siswa pada kelas kontrol kurang mampu membaca tabel yang disajikan pada soal.

\section{Kemampuan membandingkan}

Membandingkan berkenaan dengan kemampuan siswa dalam menemukan 
persamaan dan perbedaan antara dua atau lebih objek, kejadian, permasalahan, situasi dan kejadian. Rata-rata skor siswa kelas eksperimen adalah $64,88 \%$ sedangkan rata-rata skor siswa kelas kontrol sebesar 57,14\%.

Perbedaan skor yang kurang signifikan antara kelas eksperimen dan kelas kontrol ini dikarenakan sebagian besar siswa tidak mampu membedakan cermin datar, cermin cekung dan cermin cembung yang disajikan dalam bentuk gambar serta mengalami kesulitan dalam memilih pernyataan yang benar diantara pernyataan yang salah. Hal ini didukung oleh pendapat Wardono (dalam Ela Suryani, 2016) yang menyatakan bahwa dalam pemahaman konsep, siswa masih mengalami kesulitan dalam menggunakan gambar dan simbol untuk menyajikan konsep dan siswa masih mengalami kesulitan dalam mengguna kan prinsip-prinsip dasar.

\section{Kemampuan menjelaskan}

Menjelaskan merupakan kemampuan siswa dalam menjelaskan sebab-akibat yang terjadi dari berubahnya suatu sistem. Rata-rata skor siswa kelas eksperimen pada indikator pemahaman ini adalah $73,81 \%$ sedangkan kelas kontrol sebesar 55,95\%. Perbedaan perolehan skor ini dikarenakan pembelajaran dengan pendekatan konflik kognitif dikelas eksperimen, siswa secara kelompok mendiskusikan percobaan tentang sifat perambatan cahaya, pemantulan cahaya dan pembiasan cahaya sehingga mereka menemukan sendiri hubungan-hubungan fungsional tertentu, temuan inilah yang membantu mereka untuk memahami konsep dengan baik.

Hal ini sesuai dengan pendapat Roestiyah (2012) bahwasannya penggunaan metode percobaan dapat melatih siswa mencari dan menemukan sendiri berbagai jawaban atas persoalan yang dihadapinya, kemudian siswa juga akan menemukan bukti kebenaran dari teori tertentu yang sedang dipelajarinya. Rendahnya skor yang diperoleh siswa pada kelas kontrol dibandingkan kelas eksperimen dikarenakan pemahaman yang dimiliki sebagian besar siswa masih bersifat intruksional sehingga kebanyakan siswa benar pada one tier tetapi salah pada two tier atau benar pada two tier tetapi salah pada one tier. Hal ini didukung oleh pendapat Skemp (dalam Irma Hadiwiyanti, 2015) yang menyatakan bahwa pemahaman yang bersifat instruksional, siswa hanya menghapal suatu konsep dan tidak tahu mengapa suatu hal yang berkaitan dengan konsep tersebut dapat terjadi.

\section{Kesimpulan dan Saran}

Berdasarkan hasil penelitian dapat disimpulkan bahwa pemahaman konsep siswa kelas VIII SMP Negeri 40 Pekanbaru yang menerapkan pendekatan konflik kognitif lebih baik dan lebih tinggi dari pembelajaran konvensional dengan kategori pemahaman yang tergolong baik, yang mana indikator pemahaman siswa tertinggi adalah pada indikator interpretasi dan yang terendah pada indikator mengklasifikasi serta terdapat perbedaan yang signifikan antara pembelajaran fisika yang menerapkan pendekatan konflik kognitif dengan pembelajaran konvensional pada materi cahaya dan optik terhadap pemahaman konsep fisika siswa.

Sehubungan dengan kesimpulan dari hasil penelitian, untuk menerapkan pendekatan konflik kognitif dalam pembelajaran, maka diperlukan pengelolaan kelas yang baik agar tercapai tujuan pembelajaran yang telah ditetapkan. Pendekatan konflik kognitif lebih cocok dengan materi-materi fisika yang bisa dilakukan eksperimen untuk membuktikan kebenaran suatu konsep.

\section{Daftar Pustaka}

Anas Sudijono, 2009. Pengantar Evaluasi Pendidikan. Rajagrafindo Persada. Jakarta.

Ari Syahidatul Shidiq, Mohammad Masykuri \& Elfi Susanti, 2014. Pengembangan Instrumen Penilaian Two Tier Multiple Choice untuk Mengukur Keterampilan Berfikir Tingkat Tinggi pada Materi Kelarutan dan Hasil Kali Kelarutan untuk Siswa SMA/MA Kelas XI. Jurnal Pendidikan Kimia, 3(4), 83-92.

Ari Widodo, 2005. Taksonomi Tujuan Pembelajaran. Didaktis, 4(2), 61-69.

Depdiknas, 2006. Permendiknas RI No.22 Tahun 2006. Standar Isi untuk Satuan Pendidikan Dasar dan Menengah. BNSP, Jakarta. 
Ela Suryani, Ani Rusiloto, \& Wardono, 2016. Analisis Pemahaman Konsep IPA Siswa SD Menggunakan Two-Tier Test melalui Pembelajaran Konflik Kognitif. Universitas Negeri Semarang. Journal of Primary Education, 5(1), 57-63.

Fajar Subajikto, 2015. Pengaruh Strategi Pembelajaran Konstruktivisme dengan Pendekatan Konflik Kognitif dan Miskonsepsi Fisika Siswa terhadap Hasil Belajar Fisika. Prosiding Seminar Nasional Fisika (E-Journal) SNF2015. FMIPA Universitas Negeri Jakarta. Jakarta.

Irma Hadiwiyanti, 2015. Analisis Pemahaman Konsep Fisika Siswa SMP dan Penerapannya Di Lingkungan Sekitar. Skripsi. FMIPA Universitas Semarang, Semarang.

Miftahul Huda, 2011. Cooperative learning. Pustaka Pelajar, Yogyakarta.

Mosik \& Maulana, P., 2010. Usaha Mengurangi Terjadinya Miskonsepsi Fisika melalui Pembelajaran dengan Pendekatan Konflik Kognitif. Jurnal Pendidikan Fisika Indonesia, 6 (1), 98103.

Paul Suparno, 2007. Miskonsepsi dan Perubahan Konsep dalam Pendidikan Fisika. PT Grasindo, Jakarta.

Richard, E.M. \& Roxana Moreno, 2002. Animation as an aid to multimedia learning. Educational Psychology Review,14(1), 87-89.
Roestiyah, N., 2012. Strategi Belajar Mengajar. Rineka Cipta, Jakarta.

Syifa Ulya, Nathan Hindarto, \& Upik Nurbaiti, 2013. Keefektifan model pembelajaran guided inquiry berbasis think pair share dalam meningkatkan pemahaman konsep fisika siswa kelas IX SMA. Unnes Physics Education Journal, 2(3), 20.

Setyowati, A., Subali, B., \& Mosik, 2011. Implementasi Pendekatan Konflik Kognitif dalam Pembelajaran Fisika Untuk Menumbuhkan Kemampuan Berpikir Kritis Siswa SMP Kelas VIII. Jurnal Pendidikan Fisika Indonesia, 7(1), 89-96.

Sri Lestari Handayani \& Diki Rukmana, 2018. Perbandingan Miskonsepsi Mahasiswa PGSD UHAMKA Materi Optik Geometri. Jurnal Ilmiah Pendidikan Dasar, 1(5), 46.

Trianto, 2007. Model-Model Pembelajaran Inovatif Berorientasi Konstruk-tivisme. Prestasi Pustaka, Jakarta.

Umrotun, 2012. Peningkatan Pemahaman Konsep Optik melalui Teknik Inkuiri Terbimbing Peserta Didik Kelas VIII Semester Genap Tahun Ajaran 2011/2012. Jurnal Penelitian Pembelajaran Fisika, 3(1),74-82. 